\title{
RESEARCH PAPER RP1437
}

Part of Journal of Research of the National Bureau of Standards, Volume 27,

December 1941

\section{STRUCTURE OF TRICALCIUM ALUMINATE}

\author{
By Howard F. McMurdie
}

\section{ABSTRACT}

A review of the work on the structure of $\mathrm{Ca}_{3} \mathrm{Al}_{2} \mathrm{O}_{6}$ is given. The present study shows that $\mathrm{Ca}_{3} \mathrm{Al}_{2} \mathrm{O}_{6}$ has a cubic unit cell having $a_{0}=15.24 \mathrm{~A}$, and with 24 molecules present. By comparison with other compounds with similar patterns, it is seen that the metal atoms are arranged at or near the centers and corners of 3.81 A cubes. No deductions can be drawn about the oxygen arrangement from a consideration of the strong lines only.

Since there are many compounds which give patterns whose strong lines are those of a body-centered cube with $3.81 \mathrm{~A}$ edges, it is suggested that the pattern obtained by Brownmiller from slowly quenched glasses of portland cement compositions was the result of submicroscopic quench growths of metastable crystalline compounds.

\section{CONTENTS}

Page

I. Introduction

II. Previous work on the structure of $\mathrm{Ca}_{3} \mathrm{Al}_{2} \mathrm{O}_{6} \ldots$

III. Structural relations of $\mathrm{Ca}_{3} \mathrm{Al}_{2} \mathrm{O}_{8}$ to other compounds..... 500

IV. Structure of glass in portland cement clinker....

V. Summary and conclusions

VI. References_...

\section{INTRODUCTION}

Tricalcium aluminate $\left(\mathrm{Ca}_{3} \mathrm{Al}_{2} \mathrm{O}_{6}\right)$ was first identified as a distinct compound by Shepherd, Rankin, and Wright [1] ${ }^{1}$ in 1909. A few years later it was found [2] to be a product of complete crystallization at equilibrium in the system $\mathrm{CaO}-\mathrm{Al}_{2} \mathrm{O}_{3}-\mathrm{SiO}_{2}$, and from this study its occurence in portland cement clinker was predicted and subsequently verified. It is now believed to be present in many normal cement clinkers. The compound is acted upon rapidly by water, resulting in high early heat of hydration, and forms complex products with sulfates, which lower the resistance of concrete to the action of sulfate waters.

The importance of tricalcium aluminate in portland cement chemistry has resulted in several investigations to determine its crystal structure. No unique satisfactory solution of its structure, however, has yet been found. In the present paper the work on $\mathrm{Ca}_{3} \mathrm{Al}_{2} \mathrm{O}_{6}$ is reviewed, comparisons are made with diffraction patterns of other compounds, and some deductions are drawn in regard to its possible structure.

\footnotetext{
1 Figures in brackets indicate the literature references at the end of this paper.
} 


\section{PREVIOUS WORK ON THE STRUCTURE OF $\mathrm{Ca}_{3} \mathrm{Al}_{2} \mathrm{O}_{6}$}

Tricalcium aluminate was found by Rankin and Wright [2] to be isotropic with an index of refraction of 1.710 and to melt incongruently at $1,455^{\circ} \mathrm{C}$ into $\mathrm{CaO}$ and liquid. The incongruent melting of $\mathrm{Ca}_{3} \mathrm{Al}_{2} \mathrm{O}_{6}$ has made it difficult to prepare large single crystals, from which the determination of crystal class can be made by means of diffraction patterns.

Harrington [3] obtained powder diffraction patterns of $\mathrm{Ca}_{3} \mathrm{Al}_{2} \mathrm{O}_{6}$ and concluded that it was "pseudocubic" with a unit cell having $a_{0}=7.62 \mathrm{~A}$. He found six lines in the pattern to which he was not able to assign cubic indices (with a cell of $7.62 \mathrm{~A}$ ). The density indicated three molecules in this unit cell.

Steele and Davey [4] made the first attempt to find the atomic positions in the crystal. While these workers did not list the lines found by them in the pattern, they reported the cell as cubic, with $a_{0}=7.64 \mathrm{~A}$, and made no mention of any difficulty such as Harrington encountered in indexing certain lines. Steele and Davey postulated a structure in the space group $\mathrm{O}_{h}^{1}$ which accounted in an approximate way for the observed intensities. This arrangement, which had one Ca atom with no surrounding $\mathrm{O}$ atoms and one group of six $\mathrm{O}$ atoms with no central cation, planary $\mathrm{AlO}_{4}$ groups, and interatomic distances which seem unusual, appears unlikely, and consequently various workers have suggested changes.

Hermann's [5] method of producing a better balance of the valences, by placing together the extra $\mathrm{Ca}$ and the six $\mathrm{O}$ atoms, left unchanged the unusual interatomic distances.

Lagerquist, Wallmark, and Westgren [6] obtained additional powder patterns of $\mathrm{Ca}_{3} \mathrm{Al}_{2} \mathrm{O}_{6}$ and of an isostructural compound $\mathrm{Sr}_{3} \mathrm{Al}_{2} \mathrm{O}_{6}$. They concluded that $\mathrm{Ca}_{3} \mathrm{Al}_{2} \mathrm{O}_{6}$ had a cubic cell with an edge of $15.22 \mathrm{~A}$, twice that proposed by Steele and Davey with eight times jts volume. This would give 24 molecules in a unit cell. This unit cell was confirmed by Brady and Davey [14]. Büssem and Eitel [7] made Laue diagrams of the isostructural $\mathrm{Sr}_{3} \mathrm{Al}_{2} \mathrm{O}_{6}$ and concluded that the symmetry was $\mathrm{T}_{h}$. Beyond this no definite information is available. Since a similarity in pattern was found by Büssem between perovskite $\left(\mathrm{CaTiO}_{3}\right)$ and $\mathrm{Ca}_{3} \mathrm{Al}_{2} \mathrm{O}_{6}$, he considered that $\mathrm{Ca}_{3} \mathrm{Al}_{2} \mathrm{O}_{6}$ must have a perovskite structure and speculated on possible atomic positions.

\section{STRUCTURAL RELATIONS OF $\mathrm{Ca}_{3} \mathrm{Al}_{2} \mathrm{O}_{6}$ TO OTHER COMPOUNDS}

The diffraction data for $\mathrm{Ca}_{3} \mathrm{Al}_{2} \mathrm{O}_{6}$ obtained in this laboratory are given in table $1 .^{2}$ This material was prepared by heating 62.2 percent of $\mathrm{CaO}$ and 37.8 percent of $\mathrm{Al}_{2} \mathrm{O}_{3}$ just below $1,450^{\circ} \mathrm{C}$ for 4 hours. The material was then ground and reheated. This was repeated until petrographic examination indicated that the sample contained over 95 percent of one phase. These diffraction data indicate a cubic unit cell with $a_{0}=15.24 \mathrm{~A}$, in agreement with the findings of Lagerquist and coworkers. On the basis of this cell all the observed lines were indexed, including several first-order lines which could not result from a unit cell with $a_{0}=7.62 \mathrm{~A}$.

${ }^{2}$ In all patterns made for this paper, $\mathrm{CuK} \alpha$ radiation was used with cylindrical cameras having a radius of about $5.7 \mathrm{~cm}$. 
TABLE 1.-Powder diffraction data on $\mathrm{Ca}_{3} \mathrm{Al}_{2} \mathrm{O}_{6}$

[Cubic $a_{0}=15.24 \pm 0.02 \mathrm{~A}$ ]

[VS=very strong; $V W=$ very weak; $M=$ medium; $S=$ strong; $W=$ weak]

\begin{tabular}{|c|c|c|c|c|c|}
\hline Estimated intensity & $d$ & $h k l$ & Estimated intensity & $d$ & hkl \\
\hline $\begin{array}{l}W \\
V W \\
W S \\
W W \\
W W \\
V W \\
V W\end{array}$ & $\begin{array}{l}4.08 \\
3.34 \\
2.70 \\
2.39 \\
2.258 \\
2.200 \\
2.039 \\
1.984\end{array}$ & $\begin{array}{r}123 \\
124 \\
440 \\
620 \\
630-542 \\
444 \\
642 \\
731-553\end{array}$ & $\begin{array}{l}V W_{S} \\
V W^{W} \\
M \\
M \\
M \\
M\end{array}$ & $\begin{array}{l}1.951 \\
1.907 \\
1.826 \\
1.556 \\
1.346 \\
1.206 \\
1.106 \\
1.023\end{array}$ & $\begin{array}{r}650-643 \\
800 \\
653 \\
844 \\
880 \\
12.40 \\
888 \\
12.84\end{array}$ \\
\hline
\end{tabular}

Examination of these data revealed that the stronger lines considered alone defined a body-centered cubic structure with $a_{0}=3.81 \mathrm{~A}$. A similarity between these strong lines and those of other compounds has been noted by several workers. Büssem [7] found that perovskite $(\mathrm{CaTiO})$ had strong lines at the same positions as those of $\mathrm{Ca}_{3} \mathrm{Al}_{2} \mathrm{O}_{3}$, and Brownmiller [8], in a study of the system $\mathrm{CaO}-\mathrm{Na}_{2} \mathrm{O}-\mathrm{Al}_{2} \mathrm{O}_{3}$, showed that the powder diffraction pattern of $\mathrm{NaCa}_{4} \mathrm{Al}_{3} \mathrm{O}_{9}$ was also similar.

In the present investigation it has been found that the compounds of the cristobalite type [9] give a similar series of strong lines. Included in this group of compounds are high cristobalite $\left(\mathrm{SiO}_{2}\right)$, alpha carnegieite $\left(\mathrm{NaAlSiO}_{4}\right)$, and $\mathrm{Na}_{2} \mathrm{CaSiO}_{4}$. The strong lines of the last compound are most similar to those of $\mathrm{Ca}_{3} \mathrm{Al}_{2} \mathrm{O}_{6}$. $\quad \mathrm{Na}_{4} \mathrm{Ca}\left(\mathrm{SiO}_{3}\right)_{3}$ and $\mathrm{Na}_{2} \mathrm{Ca}_{3}\left(\mathrm{SiO}_{3}\right)_{3}$ also have a series of strong lines somewhat similar to those of $\mathrm{Ca}_{3} \mathrm{Al}_{2} \mathrm{O}_{6}[10]$.

From a consideration of the similarity of the strong lines of the pattern of $\mathrm{CaTiO}_{3}, \mathrm{Na}_{2} \mathrm{CaSiO}_{4}$, and $\mathrm{Ca}_{3} \mathrm{Al}_{2} \mathrm{O}_{6}$, it may be assumed that they have some structural characteristics in common. Previous investigations $[9,11]$ have reported complete structural analyses for $\mathrm{CaTiO}_{3}$ and $\mathrm{Na}_{2} \mathrm{CaSiO}_{4}$. A comparison of these two known structures would be expected to reveal what they had in common that. caused the strong lines of a body-centered lattice with $a_{0}=3.81 \mathrm{~A}$. In this way the similar strong lines in the pattern of $\mathrm{Ca}_{3} \mathrm{Al}_{2} \mathrm{O}_{6}$ might be explained.

\section{TABle 2.-Powder diffraction daia on $\mathrm{CaTiO}_{3}$}

[Cubic $a_{0}=3.82 \pm 0.02 \mathrm{~A}$ ]

[ $V S=$ very strong; $V W=$ very weak; $M=$ medium; $\mathrm{S}=$ strong; $W=$ weak]

\begin{tabular}{|c|c|c|c|c|c|}
\hline Estimated intensity & $d$ & $h k l$ & Estimated intensity & $d$ & $h k l$ \\
\hline $\begin{array}{l}W \\
W \\
W \\
W \\
W_{W} \\
S_{W} \\
M\end{array}$ & $\begin{array}{l}\text { 3. } 8 \\
2.70 \\
2.20 \\
1.905 \\
\text { 1. } 710 \\
1.558 \\
1.348\end{array}$ & $\begin{array}{l}100 \\
110 \\
111 \\
200 \\
210 \\
211 \\
220\end{array}$ & $\begin{array}{l}V W \\
M \\
V W \\
W \\
S \\
V \\
M \\
M\end{array}$ & $\begin{array}{l}1.286 \\
1.207 \\
1.099 \\
0.9562 \\
.9001 \\
.8755 \\
.8560\end{array}$ & $\begin{array}{r}300-221 \\
310 \\
222 \\
400 \\
411-330 \\
331 \\
420\end{array}$ \\
\hline
\end{tabular}

The diffraction data for $\mathrm{CaTiO}_{3}$ are given in table 2. These data indicate a cubic unit cell with $a_{0}=3.81 \AA$. The lines with $h+k+\mathrm{l}=2 n$ (those of a body-centered lattice) are the stronger. Barth [11] showed that this compound has one molecule to the unit cell and arrived at a 
structure with a Ti atom at the center and a Ca atom at each corner of the unit cell. Both the $\mathrm{Ca}$ and Ti atoms contribute to the strength of the reflections from planes with $h+k+l=2 n$, whereas the reflections from these atoms are out of phase in other planes. This would cause the lines representing a body-centered pattern to be relatively strong. Since the oxygen atoms are placed at $1 / 21 / 20,1 / 201 / 2$, and $01 / 21 / 2$, the $\mathrm{Ti}$ atom is surrounded by 6 and the $\mathrm{Ca}$ atom by 12 equally distant $\mathrm{O}$ atoms.

The diffraction data for $\mathrm{Na}_{2} \mathrm{CaSiO}_{4}$ given in table 3 represent a cubic compound with $a_{0}=7.62 \mathrm{~A}$. It is found that here, as in $\mathrm{CaTiO}_{3}$, the strong lines are those of a body-centered cube with $a_{0}=3.81 \mathrm{~A}$. Barth and Posnjak [9] worked out the atomic positions in this structure and found that with four molecules per cell, $\mathrm{Na}, \mathrm{Ca}$, and $\mathrm{Si}$ atoms were at or near the corners and centers of cubes representing oneeighth of the full cell. Here again, as in $\mathrm{CaTiO}_{3}$, all heavy atoms contribute to reflections of planes which could result from a bodycentered cube of $3.81 \mathrm{~A}$, while the reflections from these atoms are out of phase in other planes. The oxygen arrangement in this compound is completely different from that of $\mathrm{CaTiO}_{3}$. In $\mathrm{Na}_{2} \mathrm{CaSiO}_{4}$ both $\mathrm{Si}$ and $\mathrm{Ca}$ atoms are surrounded tetrahedrally, and these groups form chains by the sharing of common $\mathrm{O}$ atoms. This is a structure derived from that of high cristobalite by the substitution of Ca atoms for $\mathrm{Si}$ and the placing of $\mathrm{Na}$ atoms in the large open spaces.

TABLE 3.-Powder diffraction data on $\mathrm{Na}_{2} \mathrm{CaSiO}_{4}$

[Cubic $a_{0}=7.58 \mathrm{~A}$ ]

[VS=very strong; $V W=$ very weak; $M=$ medium; $S=$ strong; $W=$ weak]

\begin{tabular}{|c|c|c|c|c|c|}
\hline Estimated intensity & $d$ & $h k l$ & Estimated intensity & $d$ & $h k l$ \\
\hline $\begin{array}{l}S_{W} W^{W} \\
W_{S} S_{1} \\
S_{1} \\
S_{1}\end{array}$ & $\begin{array}{l}4.38 \\
3.79 \\
2.68 \\
2.170 \\
1.879 \\
1.533 \\
1.444\end{array}$ & $\begin{array}{r}111 \\
200 \\
220 \\
222 \\
400 \\
422 \\
511-333\end{array}$ & $\begin{array}{l}M \\
W \\
M \\
V W \\
V W \\
V W \\
M\end{array}$ & $\begin{array}{l}1.327 \\
1.269 \\
1.186 \\
1.141 \\
1.083 \\
1.049 \\
1.001\end{array}$ & $\begin{array}{r}440 \\
531 \\
620 \\
533 \\
444 \\
711-551 \\
642\end{array}$ \\
\hline
\end{tabular}

From the above discussion it is evident that $\mathrm{CaTiO}_{3}$ and $\mathrm{Na}_{2} \mathrm{CaSiO}_{4}$ have a cation arrangement in common, consisting of relatively heavy atoms at or near the corners and centers of cubes with an edge of $3.81 \mathrm{~A}$. The strong lines of the powder diffraction pattern of both compounds are therefore those of a body-centered cube with $a_{0}=3.81$ A. However, the important and differentiating aspects of the structure, namely, the oxygen coordination of the cations, are not shown by these strong lines.

From similarities of the positions of strong lines in the patterns of $\mathrm{CaTiO}_{3}$ and $\mathrm{Na}_{2} \mathrm{CaSiO}_{4}$ with those in the pattern of $\mathrm{Ca}_{3} \mathrm{Al}_{2} \mathrm{O}_{6}$, it may be assumed that $\mathrm{Ca}_{3} \mathrm{Al}_{2} \mathrm{O}_{3}$ also has a similar structure, with relatively heavy atoms (in this case $\mathrm{Ca}$ and $\mathrm{Al}$ ) at or near the centers and corners of 3.81 A cubes. From the similarity of these lines alone, however, no deductions can be made in regard to the oxygen arrangement.

Harrington [3] found that a density determination indicated three molecules of $\mathrm{Ca}_{3} \mathrm{Al}_{2} \mathrm{O}_{6}$ in a cell with $a_{0}=7.62 \mathrm{~A}$. In the cell with $a_{0}=15.24 \mathrm{~A}$ there are $8 \times 3$, or 24 , molecules. This would give 72 
$\mathrm{Ca}, 48 \mathrm{Al}$, and $144 \mathrm{O}$ atoms. Since there are 64 of the $3.81 \mathrm{~A}$ cubes in a full unit cell, there must be some vacant spaces, because the total of $\mathrm{Ca}$ and $\mathrm{Al}$ atoms lacks eight of filling all corner and center points.

A confirmation of this placing of the metallic atoms is found by a comparison of intensities of certain similar lines in the patterns of $\mathrm{Sr}_{3} \mathrm{Al}_{2} \mathrm{O}_{6}$ and $\mathrm{Ca}_{3} \mathrm{Al}_{2} \mathrm{O}_{6}$, compounds which appear to be isostructural. The diffraction data pertaining to $\mathrm{Sr}_{3} \mathrm{Al}_{2} \mathrm{O}_{6}$ are given in table 4. In this pattern, made under conditions identical with those pertaining to the pattern of $\mathrm{Ca}_{3} \mathrm{Al}_{2} \mathrm{O}_{6}$, it is seen, for example, that the 400 and 840 reffections are strong enough to register, while they do not appear in the pattern of $\mathrm{Ca}_{3} \mathrm{Al}_{2} \mathrm{O}_{8}$. An arrangement of the heavy atoms as outlined above would give such a result. To account for this, consider $48 \mathrm{Al}$ atoms and $16 \mathrm{Ca}$ (or $\mathrm{Sr}$ ) atoms at the centers of the 64 small cubes (such positions in the full cell as $1 / 81 / 81 / 8,1 / 83 / 85 / 8$, $5 / 87 / 81 / 8$, etc.). The other $56 \mathrm{Ca}$ (or $\mathrm{Sr}$ ) atoms are then at corners of the small cubes (such positions as $000,1 / 41 / 23 / 4,3 / 41 / 20$,etc.). Since the contribution of the oxygen atoms to the intensities would be very similar in both $\mathrm{Ca}_{3} \mathrm{Al}_{2} \mathrm{O}_{6}$ and $\mathrm{Sr}_{3} \mathrm{Al}_{2} \mathrm{O}_{6}$, let us consider only the contribution of the heavy atoms. The intensity factor, then, for the 400 and 840 planes would be

$$
56 \bar{R}-16 \bar{R}+48 \overline{\mathrm{Al}} \text {, }
$$

where $\bar{R}$ is the $F$ (scattering power) value for $\mathrm{Ca}$ or $\mathrm{Sr}$ atoms and $\overline{\mathrm{Al}}$ is the $F$ value for $\mathrm{Al}$ atoms for the particular reflection involved.

TABLE 4.-Powder diffraction data on $\mathrm{Sr}_{3} \mathrm{Al}_{2} \mathrm{O}_{6}$

[Cubic $\left.a_{0}=15.82 \mathrm{~A}\right]$

[ $V S=$ very strong; $V W=$ very weak; $M=$ medium; $S=$ strong; $W=$ weak]

\begin{tabular}{|c|c|c|c|c|c|}
\hline Estimated intensity & $d$ & $h k l$ & Estimated intensity & $d$ & $h k b$ \\
\hline $\begin{array}{l}W \\
V W \\
V W \\
V W \\
W \\
W \\
M\end{array}$ & $\begin{array}{l}5.6 \\
4.3 \\
3.96 \\
3.48 \\
2.81 \\
2.50 \\
2.28 \\
2.111 \\
1.975\end{array}$ & $\begin{array}{l}220 \\
123 \\
400 \\
124 \\
440 \\
620 \\
444 \\
642 \\
800\end{array}$ & $\begin{array}{l}V W \\
V W \\
V \\
V \\
W \\
W \\
W\end{array}$ & $\begin{array}{l}\text { 1. } 868 \\
1.773 \\
1.684 \\
1.616 \\
1.400 \\
1.317 \\
1.285 \\
1.254\end{array}$ & $\begin{array}{r}822-660 \\
840 \\
664 \\
844 \\
880 \\
884-1200 \\
10.64 \\
12.22 \\
12.40\end{array}$ \\
\hline
\end{tabular}

The $F$ values of $\mathrm{Al}$ and $\mathrm{Ca}$ are very nearly the same, so that the intensity resulting from the metal atoms would be rather small in $\mathrm{Ca}_{3} \mathrm{Al}_{2} \mathrm{O}_{6}$ compared with that in $\mathrm{Sr}_{3} \mathrm{Al}_{2} \mathrm{O}_{6}$, since the scattering power of $\mathrm{Sr}$ is about three times that of $\mathrm{Al}$.

In a preceding paragraph it was shown that no conclusions can be drawn concerning the oxygen arrangement in $\mathrm{CaTiO}_{3}$ and $\mathrm{Na}_{2} \mathrm{CaSiO}_{4}$ from a consideration of the strong lines in their diffraction patterns. It may be that the oxygen arrangement in $\mathrm{Ca}_{3} \mathrm{Al}_{2} \mathrm{O}_{6}$ is not like that in either of these compounds. This would appear probable when it is noted that in a $3.81 \mathrm{~A}$ cube of $\mathrm{CaTiO}_{3}$ there are three $\mathrm{O}$ atoms, while in $\mathrm{Na}_{2} \mathrm{CaSiO}_{4}$ there are only two and in $\mathrm{Ca}_{3} \mathrm{Al}_{2} \mathrm{O}_{8}$ there are two and a quarter $\mathrm{O}$ atoms in the same volume.

Brandenberger [12] has classified cations as: (1) active, having low coordination numbers, such as $\mathrm{Si}$ and $\mathrm{Al}$; and (2) inactive, with large coordination numbers, such as $\mathrm{Na}$. Structures with both classes are made up of oxygen polyhedrons surrounding cations of 
the first class, while cations of the second class complete the valence saturation and are placed in the large spaces with high oxygen coordination. If the activity of the calcium atoms of $\mathrm{Ca}_{3} \mathrm{Al}_{2} \mathrm{O}_{6}$ is considered, especially with regard to action with water, it is probable that in this compound, as in $\mathrm{Na}_{2} \mathrm{CaSiO}_{4}$, the $\mathrm{Ca}$ atoms, in part at least, are of the first, or active, category and have low oxygen coordination.

\section{STRUCTURE OF GLASS IN PORTLAND CEMENT CLINKER}

Brownmiller [13] prepared a series of mixtures having compositions near those of the liquids present during the heating of portland cement clinker. These mixtures all contained the oxides $\mathrm{CaO}$, $\mathrm{SiO}_{2}$, and $\mathrm{Fe}_{2} \mathrm{O}_{3}$, and in addition some had $\mathrm{Al}_{2} \mathrm{O}_{3}$. He then quenched small charges of melts of these various mixtures at two different rates. The faster quench, called instantaneous, gave in all cases isotropic products which produced no X-ray diffraction patterns. The slower quench, in which the charge stayed on the surface of the mercury and the cooling was considerably slower than in the first method, gave isotropic products, of higher index of refraction than the correspondingly fast quench. Microscopic examination of the slowly quenched material failed to reveal the presence of any crystal phases. This material produced an X-ray powder pattern consisting of the strong lines of $\mathrm{Ca}_{3} \mathrm{Al}_{2} \mathrm{O}_{6}$. This same pattern was obtained by him even in those mixtures in which no $\mathrm{Al}_{2} \mathrm{O}_{3}$ was present. The pattern, reproduced in this laboratory by similar methods, had sharp, but in most cases rather weak, lines.

Brownmiller considered this material, which gave the pattern, to be a "metastable phase." By this he indicated a structure lacking the complete randomness of glass but still having some degree of irregularity.

It would seem impossible to have sharp lines resulting from a structure with any degree of randomness. Even if the structure consisted of an oxygen network with the other atoms at random, as described by Brownmiller, the different interatomic distances $\mathrm{Fe}-\mathrm{O}$, $\mathrm{Ca}-\mathrm{O}, \mathrm{Si}-\mathrm{O}$, and $\mathrm{Al}-\mathrm{O}$ would result in a low degree of periodicity and a pattern consisting of broad lines.

Therefore, it seems more probable that the patterns in these slowly quenched samples are not the result of a semiglass material but of submicroscopic quench growths of a crystal phase. The identity of this phase is not known, but in this present work various compounds have been mentioned which give similar strong lines and doubtless others exist. Also, it is known that at high temperatures compounds form and can exist which would not be present at equilibrium conditions at lower temperatures. It is quite possible that there exists such a compound as $\mathrm{Ca}_{3} \mathrm{Fe}_{2} \mathrm{O}_{3}$ which would very likely be isostructural with $\mathrm{Ca}_{3} \mathrm{Al}_{2} \mathrm{O}_{6}$.

From the above considerations it seems very probable that the pattern obtained by Brownmiller from slowly quenched glasses is not due to a pseudocrystalline arrangement but to submicroscopic quench growths of a metastable compound. 


\section{SUMMARY AND CONCLUSIONS}

The previous work on the structure of $\mathrm{Ca}_{3} \mathrm{Al}_{2} \mathrm{O}_{6}$ was reviewed.

The present work confirms the findings of Lagerquist and coworkers that $\mathrm{Ca}_{3} \mathrm{Al}_{2} \mathrm{O}_{6}$ has a cubic unit cell with $a_{0}=15.24 \mathrm{~A}$.

The strong lines of the diffraction pattern are those of a bodycentered cube with $a_{0}=3.81 \mathrm{~A}$. These were shown to be caused by an arrangement of metal atoms at or near the corners and centers of 3.81 A cubes.

A comparison of the known structure of other compounds, which also show strong lines of a body-centered $3.81 \mathrm{~A}$ cube shows that no possible deductions can be drawn concerning the oxygen arrangements from a consideration of these strong lines.

Since there are many compounds which give patterns whose strong lines are those of a body-centered cube with $a_{0}=3.8 \mathrm{~A}$ and since a structure which has any degree of randomness will not give a pattern with strong lines, it is suggested that the pattern obtained from slowly quenched glass of portland cement materials is caused by submicroscopic quench growths of a metastable crystalline compound.

\section{REFERENCES}

[1] E. S. Shepherd, G. A. Rankin, and F. E. Wright, The system $\mathrm{CaO}-\mathrm{Al}_{2} \mathrm{O}_{3}$, Am. J. Sci. [4] 28, 293 (1909).

[2] G. A. Rankin and F. E. Wright, The system $\mathrm{CaO}-\mathrm{Al}_{2} \mathrm{O}_{3}-\mathrm{SiO}_{2}$, Am. J. Sci. [4] 39, 1 (1915).

[3] E. A. Harrington, X-ray diffraction measurements on some of the pure compounds concerned in the study of portland cement, Am. J. Sci. [5] 13, 467 (1927).

[4] F. A. Steele and W. P. Davey, Structure of tricalcium aluminate, J. Am. Chem. Soc. 51, 2283 (1929).

[5] C. Hermann, Struklus II. Ergänzungsband Z. Krist. II, 60 (Akademische Verlagsgellschaft, Leipzig, 1936).

[6] K. Lagerquist, S. Wallmark and A. Westgren, Röntgenuntersuchung der Systeme $\mathrm{CaO}-\mathrm{Al}_{2} \mathrm{O}_{3}$ und $\mathrm{SrO}-\mathrm{Al}_{2} \mathrm{O}_{3}, \dot{\mathrm{Z}}$. anorg. allgem. Chem. 234, 1 (1937).

[7] W. Büssem, X-rays and cement chemistry. Proc. of symposium on the chemistry of cements (Ingeniorsvetenskapsakadamien, Stockholm, 1938).

[8] L. T. Brownmiller and R. H. Bogue, The system $\mathrm{CaO}-\mathrm{Na}_{2} \mathrm{O}-\mathrm{Al}_{2} \mathrm{O}_{3}, \mathrm{Am}$. J. Sci. [5] 23, 501 (1932).

[9] T. F. W. Barth and E. Posnjak, Silicate structures of the cristobalite type, Z. Krist. 81, 370 (1932).

[10] R. W. G. Wyckoff and G. W. Morey, X-ray diffraction measurements upon compounds in the system soda-lime-sitica, Am. J. Sci. [5] 212, 419 (1926).

[11] T. Barth, The crystal structure of perovskite and related compounds, Norsk Geol. Tids. 8, 201 (1925).

[12] E. Brandenberger, Schweizer Archiv. angew. Wiss. Tech. 2, 24 (1936).

[13] L. T. Brownmiller, The structure of the glassy phase in portland cement clinker, Am. J. Sci. [5] 35, 241 (1938).

[14] L. J. Brady and W. P. Davey, X-ray diffraction pattern of tricalcium! aluminate, J. Chem. Phys. 9, 663 (1941).

Washington, October 14, 1941. 